\title{
Qualification of palliative nursing assistance in the use of the subcutaneous route
}

\author{
Qualificação da assistência de enfermagem paliativista no uso da via subcutânea \\ Cualificación de la asistencia de enfermería paliativa en el uso de la vía subcutánea
}

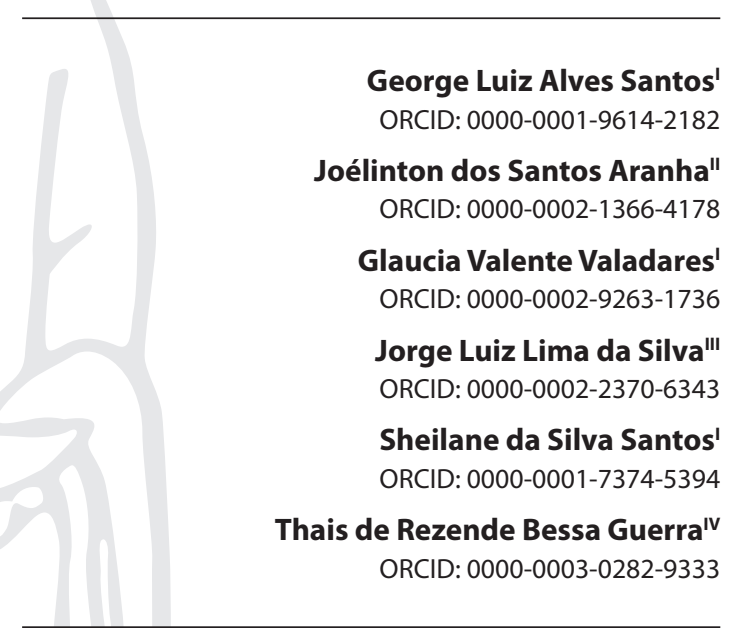

'Universidade Federal do Rio de Janeiro. Rio de Janeiro, Rio de Janeiro, Brazil. "Hospital Placi Cuidados Extensivos. Niterói, Rio de Janeiro, Brazil. "'Universidade Federal Fluminense. Niterói, Rio de janeiro, Brazil "Faculdade Bezerra de Araújo. Rio de Janeiro, Rio de Janeiro, Brazil

How to cite this article: Santos GLA, Aranha JS, Valadares GV, Silva JLL, Santos SS, Guerra TRB. Qualification of palliative nursing assistance in the use of the subcutaneous route. Rev Bras Enferm. 2020;73(5):e20190056. doi: http://dx.doi.org/10.1590/0034-7167-2019-0056

\section{Corresponding author: \\ George Luiz Alves Santos \\ E-mail: georgealvesrad@hotmail.com}

EDITOR IN CHIEF: Dulce Aparecida Barbosa ASSOCIATE EDITOR: Margarida Vieira

Submission: $07-19-2018$

Approval: 12-10-2019

\begin{abstract}
Objectives: to describe the experience of conducting workshops for teaching the subcutaneous fluid infusion therapy in palliative care patients. Methods: experience report based on four workshops with a workload of nine hours each, addressing the teaching, implementation of the technique, and management in the use of subcutaneous fluid infusion therapy in patients in palliative care. The host institution was a private hospital, which had two care units in the state of Rio de Janeiro. Results: we identified little knowledge about the theme. Due to the dynamics used, the workshops made it possible to qualify the participants to perform and manage the subcutaneous route in palliative care environments. Conclusions: the workshops were an important means of training, qualification, and dissemination of nursing care in a palliative care environment. The resources used to enable the qualification in the execution and management of the presented technique.
\end{abstract}

Descriptors: Geriatric Nursing; Palliative Care; Nursing Care; Drug Administration Routes; Hypodermoclysis.

\section{RESUMO}

Objetivos: descrever a experiência da realização de oficinas para o ensino da terapia de infusão de fluidos por via subcutânea em pacientes em cuidados paliativos. Métodos: relato de experiência baseado em quatro oficinas com carga horária de nove horas cada, abordando o ensino, a execução da técnica e o manejo na utilização da terapia de infusão de fluidos por via subcutânea em pacientes em cuidados paliativos. A instituição sediadora foi um hospital privado, que contava com duas unidades assistenciais no estado do Rio de Janeiro. Resultados: identificou-se pouco conhecimento acerca da temática. Pela dinâmica utilizada, as oficinas possibilitaram qualificar os participantes a executarem e a manejarem a via subcutânea em ambientes de cuidados paliativos. Conclusões: as oficinas foram importante meio de formação, qualificação e divulgação do cuidado de enfermagem em ambiente de cuidados paliativos. Os recursos utilizados possibilitam a qualificação na execução e no manejo da técnica apresentada. Descritores: Enfermagem Geriátrica; Cuidados Paliativos; Cuidados de Enfermagem; Vias de Administração de Medicamentos; Hipodermóclise.

\section{RESUMEN}

Objetivos: describir la experiencia de la realización de talleres para la enseñanza de la terapia de infusión de fluidos por vía subcutánea en pacientes en cuidados paliativos. Métodos: relato de experiencia basado en cuatro talleres con carga horaria de nueve horas cada, abordando la enseñanza, la ejecución de la técnica y el manejo en la utilización de la terapia de infusión de fluidos por vía subcutánea en pacientes en cuidados paliativos. La institución acogedora ha sido un hospital privado, que ha contado con dos unidades asistenciales en el estado de Rio de Janeiro. Resultados: se identificó poco conocimiento acerca de la temática. Por la dinámica utilizada los talleres posibilitaron calificar los participantes a ejecutaren y a manejaren la vía subcutánea en ambientes de cuidados paliativos. Conclusiones: Los talleres han sido importante medio de formación, cualificación y divulgación del cuidado de enfermería en ambiente de cuidados paliativos. Los recursos utilizados posibilitan la cualificación en la ejecución y en el manejo de la técnica presentada.

Descriptores: Enfermería Geriátrica; Cuidados Paliativos; Cuidados de Enfermería; Vías de Administración de Medicamentos; Hipodermóclisis. 


\section{INTRODUCTION}

Palliative care comprises approaches that focus on the quality of life of patients and families when considering the problems associated with life-threatening diseases ${ }^{(1)}$. In this context, nursing, a participant in the interdisciplinary team, should be guided by accurate assessment and early recognition, in order to prevent and alleviate suffering. It should recognize and treat pain as well as other symptoms without disregarding psychosocial and spiritual issues ${ }^{(1)}$, which often involves pharmacological measures for symptom control.

In the routine of palliative care, nurses and nursing technicians have used the subcutaneous route for the administration of drugs and solutions, aiming such measures. The term "hypodermoclysis" is suitable when it is used continuous infusions of larger volume solutions into subcutaneous tissue. When there is a bolus infusion of a drug in which a small volume is administered, It is usual to describe this practice as using the subcutaneous route ${ }^{(2)}$ and not as hypodermoclysis. It has been commonly used in geriatric and palliative care services for its considerable advantages over potential complications ${ }^{(3)}$.

Knowledge about this technique is still incipient. A recent study, which sought publications on the subject, identified few articles on it, namely: four produced in Brazil; four in the United States; one in Germany; one in Cuba; and one in Switzerland ${ }^{(4)}$. Of these, only three had nurses as authors. Thus, the justification of this discussion emerges, as well as the presentation of the teaching strategy.

Subcutaneous fluid infusion therapy is an alternative route when venous access is difficult, or it is a difficult oral fluid intake, if present, for example, incoercible vomiting with nausea, diarrhea, drowsiness, and mental confusion, among other symptoms. This therapy then becomes an alternative for electrolyte replacement, solutions, and drug delivery ${ }^{(5)}$, which should be slowly administered into the subcutaneous space as this fluid is transferred to the bloodstream by combined action between fluid diffusion and tissue perfusion ${ }^{(6)}$.

As for the place of choice for a puncture, studies recommend choosing regions with the highest amount of subcutaneous tissue $^{(3)}$. When inserting a catheter, it is necessary to take care to preserve patient comfort, mobility, and independence. The most eligible regions are the thoracic and abdominal walls - the latter for larger volumes. The chest region should be avoided for patients with cachexia because of the risk of pneumothorax. Also, as a secondary site, upper limbs may be used for puncture in the deltoid region; and the lower limbs in the anterolateral region of the thigh and also in the subclavicular region ${ }^{(2)}$.

The activity on screen was developed after an exhaustive search, at the time, for specialized training and improvement in the use of subcutaneous fluid infusion therapy in traditional teaching environments. In the state of Rio de Janeiro, the lack of learning opportunities surprised the authors of this report, as the state has a national benchmark service for cancer patients. The technique was used, but with the knowledge acquired from peers and available scientific literature, without specific training for management and its use.

\section{OBJECTIVES}

To describe the experience of conducting workshops for teaching the subcutaneous fluid infusion therapy in palliative care patients.

\section{METHODS}

An experience report based on four workshops held in a private hospital, which had two care units in two cities of the state of Rio de Janeiro, Niterói and Rio de Janeiro. Each workshop was organized at levels of the increasing complexity of content and knowledge, initiating in the theoretical aspects and culminating with simulated execution of the technique by each participant. We structured the workshops from the writing and presentation of a project to the institution's board and nursing management. These were disseminated through social media.

This experience report dispenses the requirement to submit it to the Research Ethics Committee, as it did not focus on participants or the use of their speeches. Similarly, we only characterized the place where the activity took place without its identification. The report focused on the description of the activity and teaching experience, aiming at the theoretical deepening of the reported activity. Finally, it is understood that this work does not violate any ethical precepts in research, considering the specific resolutions that address the theme.

\section{RESULTS}

In 2017, we ministered four workshops: one in May, with 18 students; one in June with 13 students; the third in August, with ten students; and the last one in December, with 16 students totaling, among nurses, academics and nursing technicians, 57 students qualified for the execution and management of the technique. Participants of the workshops were inside and outside professionals, who did not work in the institution, unfolding in a moment of updating and training of professionals. This work was an essential strategy for continuing education and contributed to the increase of quality of care, by acquiring a consistent theoretical base, combined with daily practice.

We sought consent from the head of the nursing department and the institutional medical administration by writing and presenting the project in a meeting where there was discussion about the details of the proposal and the necessary resources. Besides, meetings were held with other sectors of the hospital, such as hospitality, information technology (IT), and nutrition, to discuss the logistics and structuring of the workshop, like parking spaces, snacks, and lunch offered on to participants. After authorization, we operationalized the proposal.

For dissemination, we used the institutional social media and the facilitators, that is, the nurses who worked in the institution. We made a poster with the following call: "Theoretical and practical course, with the execution of the insertion technique of non-needled catheter (jelco) or needled catheter (scalp) in subcutaneous tissue. The simulated practice will be on a mannequin, addressing the installation, administration of medications, and solutions, as well as the management of the subcutaneous fluid infusion therapy. The objective is to qualify the participant 
for the performance of primary and low complexity functions, regardless of previous technical knowledge and previous professional experience, providing updates related to indications, contraindications, main complications, and nursing care involved in the use of subcutaneous route in adult and senior customers."

The course lasted one day, with nine hours of workload, divided into four theoretical hours and five hours of simulated practical activities on a mannequin, plus an hour break for lunch. We repeated on three more dates, totaling four workshops. Another strategy was the use of thawing chicken breast cuts (Gallus gallus domesticus) intended for skin folding to perform the technique. The teaching activities took place in the hospital training room. It is noteworthy that the technique was performed at all times on a mannequin and was not performed in vivo.

There was a lesson plan, which is an effective resource in the structuring of theoretical knowledge. The teaching strategy was as lecture and use of dialogue circle. Also, as a resource for practical simulation, there was a puncture kit containing a $21 \mathrm{G}$ needle catheter (scalp), a 24G non-needle catheter (jelco), a $5 \mathrm{~mL}$ syringe and a $40 \times 12$ aspiration needle, a $10 \mathrm{~mL}$ flask of $0.9 \%$ saline and an infusion extension line. We used transparent tape and microporous tape ${ }^{(2)}$ to demonstrate the attachment of the device and the protection of the punctured site.

Thus, the syllabus design was to, in the morning, build the theoretical basis of knowledge and the sharing of experiences, namely: brief history of the use of subcutaneous fluid infusion therapy; chronic diseases and palliative care; use of the subcutaneous route; regulation; legislation on the subject; subcutaneous route: anatomical and physiological aspects; relationship with pharmacological parameters; indications/contraindications; advantages disadvantages; solutions, drugs, and antibiotic therapy; compatibility and incompatibilities; procedure, which included necessary material, choice of puncture site; management in the use of subcutaneous fluid infusion therapy; and professional record (annotations and evolution). In the afternoon, we made a technical visit in the hospital premises with all students participating in the four editions, to know the physical structure and work philosophy, allowing the sharing of knowledge and practices among professionals.

With the feedback from previous classes, we developed a technical product, making an illustrated material, with the sequence of steps for the execution of the technique, and photos of each moment, from the individually arranged materials to the assembled tray. One of the authors was a model for the execution of the in vivo technique, in the sequenced images. This strategy was useful in projecting the images to expose the theoretical content.

We demonstrated all the necessary material, such as the assembly of the tray for the execution of the technique. We also made an overview of the various experiences, building the possibilities of realization of the technique in both the private and public hospital sectors, since, among the participants, it was possible to perceive several scenarios of performance and different realities regarding the available resource. Nevertheless, always based on theory without breaking the precepts of an aseptic technique. There was also a step-by-step demonstration of the procedure on the mannequin or chicken breast.

Then, participants had the opportunity to perform the simulated practice, with supervision, on a mannequin at least twice, with the execution of the technique as well as training and individual advice by the facilitating nurses responsible for the workshop, making use of the puncture kit received. Although the proposal has developed questions regarding the technique, it was possible to address the attributes appropriate to better care.

At the end of the practical activity, participants were divided into groups of four participants to discuss a simulated clinical case. They should point the diluents to the drug in question, the most indicated puncture site according to volume, and, finally, how many puncture sites would be relevant to using subcutaneous fluid infusion therapy and how to approach families in cases of more than one puncture site. Assistance in management and use of the technique - nursing care were also considered.

\section{DISCUSSION}

The contents and objectives of this report are in harmony with another study, which focused on similar activity, information on the concept of hypodermoclysis, indications, contraindications, advantages, puncture sites, technique, drugs used, dilution, ways of dilution, in addition to nursing care in puncture, management, and monitoring of the device ${ }^{(7)}$. Thus, it is possible to infer what would be the minimum knowledge required for the proper execution and management of the technique safely.

Throughout their editions, the workshops allowed the presentation of the technique, commonly unknown among most participants, who often questioned:"Is this a new technique?"This finding, identified by the initial presentation dynamics of each participant at the beginning of the activity, was emphasized by a large number of undergraduate students and nurses with little training time. The technique was common among participants resident in oncology. Few people claimed to have performed it, especially residents of oncology. Other studies corroborate this finding regarding the lack of knowledge of the technique ${ }^{(3,8-9)}$.

It is necessary to rethink which contents formal teaching environments have been developing so that those presented in this experience report should be further discussed within the scope of vocational training, whether higher or technical. Training human resources that meet the reality of health needs is a challenge to be faced by educational institutions, which, in teaching, must extrapolate the most traditional drug administration techniques.

We presented the institutional protocol, in which participants had the opportunity to visualize how the workshop facilitators experienced daily professional practice in the use of the technique. The protocol was a result of difficulties experienced by the facilitating nurses, and, on each occasion, there were moments of discussion between them and the participants. They expressed the local reality of their services and questioned how they could make the proposed protocol possible in their institution. Thus, each participant clearly visualized the standardization of the technique used, and their doubts were answered - for example, "How did you standardize the technique?".

Workshop participants were understood as qualified human resources regarding the implementation and management of the technique, acquiring knowledge aiming to develop safe care practices, which is a reduction in care risks and adverse events. Therefore, they acquired competence to perform them in an "act 
responsibly, which is recognized by others in a dynamic that implies knowing how to mobilize, integrate and transfer resources, knowledge, and competencies in a particular professional context"(10).

Regarding the maximum volumes deposited in the subcutaneous tissue, some participants mentioned that the technique presented contradicted what they have learned in nursing fundamental classes. We demystified this construction, signaling that it was a technique with specific indications of use. Maximum volumes, when using subcutaneous fluid infusion therapy, vary by site and therapeutic proposal. For larger volumes, the anterolateral thigh (up to $1,500 \mathrm{~mL}$ / 24 hours), abdominal (up to 1,000 mL/24 hours) and interscapular (up to $1,000 \mathrm{~mL} / 24$ hours) sites would be considered; when smaller volumes are infused, subclavicular (up to $250 \mathrm{~mL} / 24$ hours) and deltoid (up to $250 \mathrm{~mL} / 24$ hours) regions are considered ${ }^{(2)}$.

Another oddity recognized during the workshop was when equipment, such as needle and non-needle catheters, was presented because until then, most participants associated with the subcutaneous only the administration of low molecular weight insulin and heparin with low-gauge needles $(13 \times 4.5 \mathrm{~mm})$. In the first moments, the pertinent literature was presented, indicating each device (2) as well as its use in subcutaneous fluid infusion therapy.

Due to the lower cost, the literature points to the needle catheter (scalp) as of common use ${ }^{(9)}$. However, in the workshops, we decided to indicate the non-needle catheter regular use because of a higher possibility of the length of stay and a detachment of the protective film that fixes the device due to heavy sweating or even frequent patients mobilization. Also, accidental removal of the device may occur at the time of care, increasing occupational accidents or even with the patient himself.

Participants exhibited difficulty in skin fold formation and quality assessment, for which the literature indicates subcutaneous tissue thickness between 1.0 and $2.5 \mathrm{~cm}^{(2)}$ when considering subcutaneous fluid infusion therapy. The strategy adopted by the facilitators was of each participant to execute the simulated skinfold in thawing chicken breasts.

The presentation of each step required to perform the technique followed a logical order, from tray assembly to replication of the mannequin technique. This plan made it possible to systematize learning, which was referred by the students as facilitating the global understanding of the content, integrating theoretical and practical knowledge.

Correct puncture management was emphasized in essential care to minimize unwanted occurrences. We discussed with the participants the following nursing care: hand hygiene before each catheter handling; performing asepsis of the access route whenever the system is opened, as well as friction of the access lumen ostium with 70\% alcohol-soaked gauze; changing the Luer Lock cap on each handling if in a hospital environment; counseling patients, family members and staff regarding the possibility of mild hyperemia and edema at the catheter insertion site soon after puncture; and puncture protection during hygiene and comfort care ${ }^{(2)}$.

Another highlight of the developed activity was the discussion about the technique being of low complexity and, therefore, it can also be performed by the nursing technician, as long as it is delegated and supervised by a nurse, and the technician has training and technical skill. This data is pertinent because the workshop was sought by mid-level professionals, with the discourse of professional qualification, highlighting that its mastery would be a differential for the curriculum.

To enhance learning and assess participants' understanding, they were organized in small groups and presented clinical cases in a printed worksheet, based on the theoretical content worked in the morning. There were questions to stimulate clinical reasoning and content problematization - for example: "What is the diluent indicated for each drug in this case? How many puncture sites would be required considering the prescription? Would there be incompatible drugs in the case presented? If so, how to proceed?" This dynamic allowed identifying contents to be discussed in greater depth, considering the resolution of the cases.

The questions raised by the participants regarding medications, especially about which drugs indication and how they should be diluted and administered, were present in all four workshops. It was considered the importance of discussing with participants what the literature considers to administer a drug in this way, namely: $\mathrm{pH}$, stability, dilution volumes, and appropriate diluents ${ }^{(8)}$. As a strategy to minimize doubts, we suggested developing a protocol for the use of subcutaneous fluid infusion therapy, which should include the most commonly used drugs, diluents, and administration form, in charts prepared with such information ${ }^{(2,8)}$.

Most of the participants' doubts were about the catheter insertion site, which was worked by the technique execution, reinforcing the information that they should insert the device in the fold, and not in its base, a fact that could potentiate the positioning of the catheter device out of the indicated place - for example, in a muscle.

Doubts regarding site infusion volumes were resolved by demonstrating each topographic landmark on the mannequin. The dilution of the drugs was discussed with a chart made in the Word program, which was printed and delivered to workshop participants. It contained the name of the drug, usual dose, and dilution. Regarding the formation and evaluation of the skinfold, the participants simulated its formation in thawing chicken breast cuts.

A critical moment for ethical reflection of nursing care was related to the approach of families, which go through a process of suffering - which is beyond the domain of a technique. Thus, in addition to the specialized technician, we approached the context of the performance of the technique - in this case, the palliative care environment. As the subcutaneous route is a minimally invasive comfort promotion instrument, the purpose of nursing care to promote comfort with minimal invasion of the patient's body was considered for this discussion. Nurses should perform the care competencies in this scenario, especially the assessment, management, and control of signs and symptoms, without disregarding a care plan that encompasses the physical, psychological, social, and spiritual dimensions, impacting the patient's quality of life ${ }^{(9)}$ in palliative care.

\section{Study Limitations}

The workshop model applied with the theoretical and practical characteristics adopted met the objectives of the activity. However, the use of mannequin and thawing chicken breast cuts was understood as simulated practice models that approached but did not faithfully reproduce the real environment. Likewise, the number of times each participant practiced the technique enabled the apprehension of how to perform it; however, insecurities may 
arise when practicing in real care settings. The results presented and discussed raise questions that require further studies and practical evidence in nursing education.

\section{Contributions to nursing, health, or public policy fields}

This experience report contributed to the qualification of the professional practice of nurses and nursing technicians, or even professionals in training, in the care of patients in palliative care and comfort measures. Mastery of fundamental techniques translates into critical, quality, and results-oriented practice - in this case, promoting minimally invasive care and proper management. Although it is a low complexity technique, it requires specialized practice in the installation and proper management of subcutaneous use, resulting in specialized care, in addition to ensuring the quality of care.

\section{CONCLUSIONS}

This report, evidenced in the performance of teaching for qualification, contributed to the theoretical and practical training of nurses, technicians, and nursing students, sometimes presenting the technique as the first contact, sometimes allowing deepening to those who already used it. The activity consisted of a moment of learning and exchange of experiences, as the proposal of workshops emerged from the experience of facilitating nurses, which were oriented to practice.

The workshops fulfilled the objective of presenting the necessary knowledge for the management of the technique and enabling its execution, helped in the construction of theoretical bases for autonomous and quality assistance, which has repercussions on the dissemination and consolidation of specialized disciplinary knowledge, giving greater visibility to the performance of the nurse and the team in palliative care environments. By training more than 50 participants to use the subcutaneous route in adult and elderly clients, they contributed to the training of specialized nursing human resources to become more able to offer quality and safe care.

\section{ACKNOWLEDGMENT}

Acknowledgments to the Placi Extensive Care Hospital.

\section{REFERENCES}

1. Sociedade Brasileira de Geriatria e Gerontologia (SBGG). Vamos falar de Cuidados Paliativos [Internet]. Rio de Janeiro: SBGG, 2015 [cited 2018 Jun 21]. Available from: https://sbgg.org.br//wp-content/uploads/2015/05/vamos-falar-de-cuidados-paliativos-vers--o-online.pdf

2. Sociedade Brasileira de Geriatria e Gerontologia (SBGG). O uso da via subcutânea em geriatria e cuidados paliativos [Internet]. $2^{a}$ ed. Rio de Janeiro: SBGG, 2017 [cited 2018 Jun 21]. Available from: http://sbgg.org.br/wp-content/uploads/2014/11/SBGG_guia-subcutanea_2aedicao.pdf

3. Nunes PM, Souza RC. [Adverse effects of hypodermoclysis in adult patients: an integrative review]. Rev Min Enferm [Internet]. 2016 [cited 2018 Jun 21]; 20:e951. Available from: http://www.reme.org.br/artigo/detalhes/1084 Portuguese.

4. Brito WA, Chibante CL, Espírito Santo FH. Hipodermóclise: ferramenta terapêutica para o cuidado de enfermagem e saúde. Rev Cubana Enferm [Internet]. 2017 [cited 2018 Jun 21];33(4). Available from: http://revenfermeria.sld.cu/index.php/enf/article/view/1182

5. Oliveira SS, Sousa JA, Silva SdF, Jeremias WJ. Infusão subcutânea de analgésicos em pacientes oncológicos sob cuidados paliativos: uma revisão de literatura. e-Scientia. 2014;7(1).

6. Agência Nacional de Vigilância Sanitária (ANVISA). Medidas de Prevenção de Infecção Relacionada à Assistência à Saúde [Internet]. 2a ed. Brasília, DF: Anvisa, 2017 [cited 2018 Jun 21]. Série Segurança do Paciente e Qualidade em Serviços de Saúde. Available from: http://portal. anvisa.gov.br/documents/33852/3507912/Caderno+4+-+Medidas+de+Prevenção+de+Infecção+Relacionada+à+Assistência+à+Saúde/ a3f23dfb-2c54-4e64-881c-fccf9220c373

7. Rodrigues FS, Pedra MC, Santos JL, Rumor PC, Girondi JB, Oliveira MC. Continuing education on hypodermoclysis with the nursing team of a hospital surgical unit. Rev Enferm UFPE [Internet]. 2015 [cited 2018 Jun 21];10(3):1562-70. Available from: https://periodicos.ufpe.br/ revistas/revistaenfermagem/article/view/11098

8. Bruno VG. Hypodermoclysis: a literature review to assist in clinical practice. Einstein (Sao Paulo). 2015;13(1):122-8.

9. Gomes NS, Silva AMBD, Zago LB, Silva ÉCLE, Barichello E. Nursing knowledge and practices regarding subcutaneous fluid administration. Rev Bras Enferm. 2017; 70(5):1096-105. doi: 10.1590/0034-7167-2016-0424

10. Sousa JM, Alves ED. Nursing competencies for palliative care in home care. Acta Paul Enferm [Internet]. 2015 [cited 2018 Jun 21];28(3):264-9. Available from: https://www.scielo.br/pdf/ape/v28n3/en_1982-0194-ape-28-03-0264.pdf 